\title{
Social impact of Mahatma Gandhi National Rural Employment Guarantee Act (MGNREGA) in Hoshiarpur district : A socio-economic study
}

Neha Wasal

Arya College, Ludhiana (Punjab) India

(Email : neha_wasal@yahoo.com)

\section{ARTICLE INFO :}

$\begin{array}{lll}\text { Received } & : & 23.09 .2019 \\ \text { Revised } & : & 08.11 .2019 \\ \text { Accepted } & : & 25.11 .2019\end{array}$

\section{KEY WORDS :}

National Rural Employment Guarantee Act, Rural development, Employment opportunity, Rural connectivity, Sarpanch

\section{HOW TO CITE THIS ARTICLE :}

Wasal, Neha (2019). Social impact of Mahatma Gandhi National Rural Employment Guarantee Act (MGNREGA) in Hoshiarpur district : A socio-economic study. Adv. Res. J. Soc. Sci., 10 (2) : 6065, DOI: 10.15740/HAS/ARJSS/10.2/ 60-65. Copyright@2019 : Hind Agri Horticultural Society

\section{ABSTRACT}

National Rural Employment Guarantee Act (NREGA) aimed at providing direct employment to the deserving rural people has been in operation for last many years. The present study had conducted to assess the role of NREGA programme with the following specific objectives: to study socio-economic profile of the beneficiaries of NREGA, to assess the contribution of NREGA in socio-economic development of its beneficiaries, to identify the factors of success and failure and to render suitable suggestions for further improvement in the NREGA programme. Socio-economic profile of the respondents revealed that most of the respondents were male, in the middle age group, hailing from schedule caste category and were having little education and low income level. The profile of beneficiaries of NREGA programme indicated that the benefits of this programme is going to the deserving people. Rural connectivity (repair of roads etc.), village cleanliness, plantation were the major areas in which the NREGA beneficiaries worked under the supervision of a Mate. The village Sarpanch proved to be the major person who made aware to the beneficiary and helped them to get employment under this programme. On an average beneficiary of NREGA got employment for 15 days in a month. All the beneficiaries of the NREGA programme got prescribed wage i.e. Rs. 123 per day which was paid timely to the respondents. $1 / 5^{\text {th }}$ of the respondents held that dependency on the farmers had reduced after joining NREGA programme and also wage rate had increased in other activities in villages due to the arrival of NREGA programme. 38 per cent of the respondents opined that NREGA activities helped them to remove idleness whereas 25 per cent of respondents felt more social recognized after joining NREGA. Overall the launching of NREGA programme had increased the demand for labour in rural areas. The non- beneficiary of NREGA programme did not join the NREGA largely due to social inhibition (not ready to do labour in own village), low wage rate and irregularity of work. Irregular grants and work opportunities, less wage rate were the major constrains experienced by the beneficiaries of NREGA. Regularity in grants, generating adequate employment opportunity may prove more useful for NREGA beneficiary and society at large. 